\title{
G1/S-Specific Cyclin-D2
}

National Cancer Institute

\section{Source}

National Cancer Institute. G1/S-Specific Cyclin-D2. NCI Thesaurus. Code C45487.

G1/S-specific cyclin-D2 (289 aa, $33 \mathrm{kDa}$ ) is encoded by the human CCND2 gene. This protein plays a role in the G1/S transition of the cell cycle. 